\title{
Am/Cm Melter Processing Limitations Evaluation for Product Loading Extremes
}

by

M. E. Stone

Westinghouse Savannah River Company

Savannah River Site

Aiken, South Carolina 29808

T. M. Jones

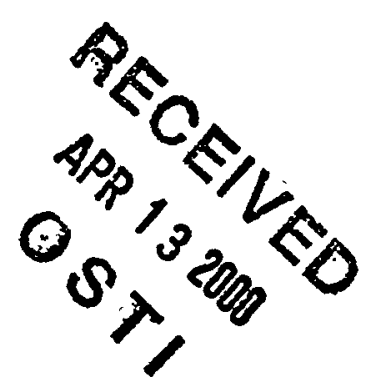

DOE Contract No. DE-AC09-96SR18500

This paper was prepared in connection with work done under the above contract number with the $U$. S.

Department of Energy. By acceptance of this paper, the publisher and/or recipient acknowledges the U. S.

Government's right to retain a nonexclusive, royalty-free license in and to any copyright covering this paper, along with the right to reproduce and to authorize others to reproduce all or part of the copyrighted paper. 


\section{WESTINGHOUSE SAVANNAH RIVER COMPANY WSRC-TR-99-00475TL SAVANNAH RIVER TECHNOLOGY CENTER}

Date: $2 / 7 / 2000$

TO: W. H. MARTIN, 730-2B

FROM: L. F. LANDEN, 704-1T

AM/CM MELTER PROCESSING LIMITATIONS EVALUATION FOR PRODUCT LOADING EXTREMES (U)

Per Task 3.06 of TTR-NMSS/SE-006, ITS performed several vitrification runs in the 5-inch Cylindrical Induction Melter (CIM5) to evaluate the system's ability to process potential product loading extremes about the reference glass loading target of $49 \mathrm{wt} \% \mathrm{Ln}$. Vitrification cycles were performed targeting product loadings of $53 w t \%$ Ln, $51 w t \%$ Ln, $47 w t \% \operatorname{Ln}$ and $45 w t \%$ Ln.

The major conclusion from these tests is that the propensity for a bed expansion is linked to the quantity of cullet batched to the melter. Based on these tests, an overcharge greater than $13 \%$ above the baseline amount of cullet could result in a severe bed expansion.

Please refer any questions you may have regarding the contents of this document to T. M. Jones (Ext. 7-7706) or M. E. Stone (Ext. 7-7751).

\section{DISTRIBUTION}

J. T. Dahlstrom, 730-1B

A. W. Bowers, $704-10 \mathrm{~F}$

A. P. Giordano, $730-1 \mathrm{~B}$

A. P. Fellinger, $730-1 \mathrm{~B}$

N. H. Harkey, $730-1 B$

D. C. Witt, 704-1T

D. H. Miller, 704-1T

STI 703-43A (4) 


\section{AM/CM MELTER PROCESSING LIMITATIONS EVALUATION FOR PRODUCT LOADING EXTREMES}

T. M. JONES

M. E. STONE

Publication Date: 2/2/2000

Westinghouse Savannah River Company Savannah River Site Aiken, SC 29808

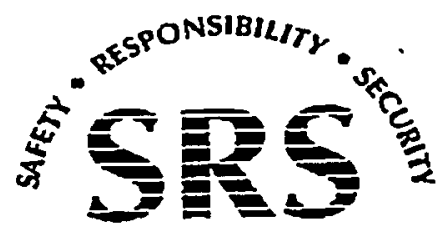

SAVANNAH RIVER SITE PREPARED FOR THE U.S. DEPARTMENT OF ENERGY UNDER CONTRACT NO. DE-AC09-96SR18500 


\section{DISCLAIMER}

This report was prepared as an account of work sponsored by an agency of the United States Government. Neither the United States Government nor any agency thereof, nor any of their employees, makes any warranty, express or implied, or assumes any legal liability or responsibility for the accuracy, completeness, or usefulness of any information, apparatus, product or process disclosed, or represents that its use would not infringe privately owned rights. Reference herein to any specific commercial product, process or service by trade name, trademark, manufacturer, or otherwise does not necessarily constitute or imply its endorsement, recommendation, or favoring by the United States Government or any agency thereof. The views and opinions of authors expressed herein do not necessarily state or reflect those of the United States Government or any agency thereof.

This report has been reproduced directly from the best available copy.

Available for sale to the public, in paper, from: U.S. Department of Commerce, National Technical Information Service, 5285 Port Royal Road, Springfield, VA 22161, phone: (800) 553-6847

fax: (703) 605-6900

email: orders@ntis.fedworld.gov

online ordering: http://www.ntis.gov/ordering.htm

Available electronically at http://www.doe.gov/bridge

Available for a processing fee to U.S. Department of Energy and its contractors, in paper, from: U.S. Department of Energy, Office of Scientific and Technical Information, P.O. Box 62, Oak Ridge, TN 37831-0062, phone: (865) 576-8401

fax: (865) 576-5728

email: reports@adonis.osti.gov 


\section{DISCLAIMER}

\section{Portions of this document may be illegible in electronic image products. Images are produced from the best available original document.}


WSRC-TR-99-00475

ITS Activity No. ITS-99-0100

Keywords: Am/Cm, CIM5, Ln Loading

Retention: Permanent

\section{AM/CM MELTER PROCESSING LIMITATIONS EVALUATION FOR PRODUCT LOADING EXTREMES}

T. M. JONES

M. E. STONE

Publication Date: 2/2/2000

Westinghouse Savannah River Company

Savannah River Site

Aiken, SC 29808

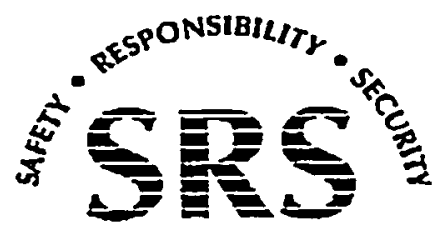

PREPARED FOR THE U.S. DEPARTMENT OF ENERGY UNDER CONTRACT NO. DE-AC09-96SR18500 
APPROVALS

ME $\mathbb{A C}$ for T.M. Sones

T. M. Jones, Author Immobilization -Technology Section

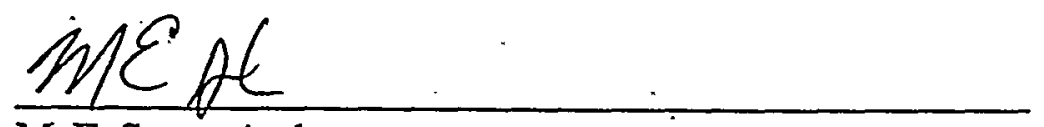

M. E. Stone, Author Immobilization Technology Section

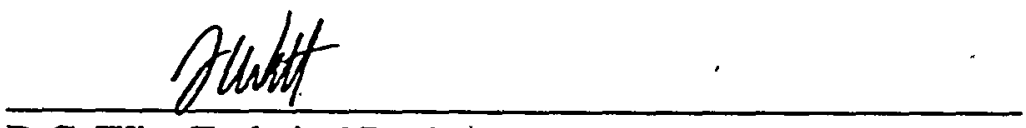

D.C. Witt, Technical Reviewer Immobilization Technology Section

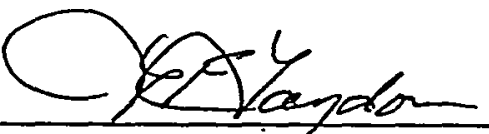

L. F. Landon, Manager Immobilization Technology Section $\frac{2 / 2 / 00}{\text { Date }}$

$\frac{2 / 2 / 00}{\text { Date }}$

$\frac{2 / 2 / 00}{\text { Date }}$

$\frac{2 / 3 / 00}{\text { Date }}$ 


\section{TABLE OF CONTENTS}

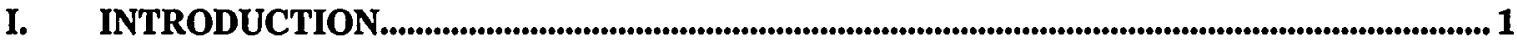

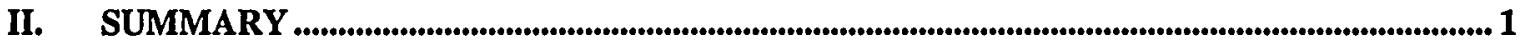

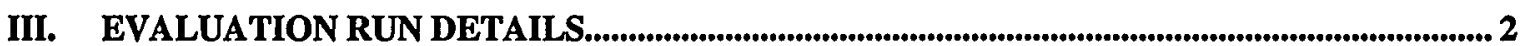

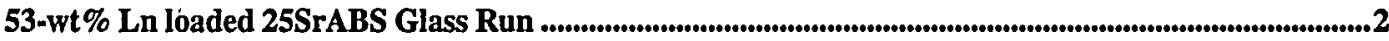

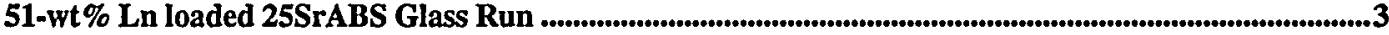

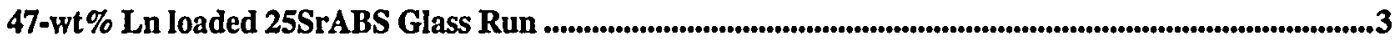

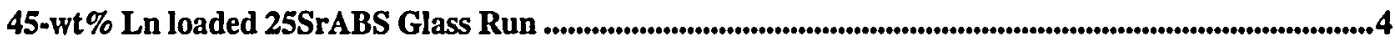

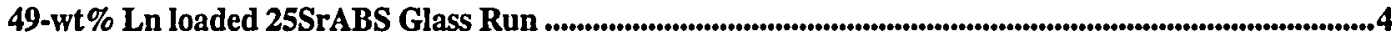

45-wt \% Ln loaded 25SrABS Glass Run (77g/L Oxides)........................................................................................4

IV. EFFECT OF VARIATION IN PROCESS ON LANTHANIDE CONTENT OF GLASS ............8

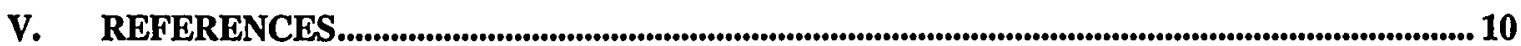


WSRC-TR-99-00475

ITS-99-0100

Page 1 of 11

\section{INTRODUCTION}

Six vitrification runs were conducted in the 5 inch Cylindrical Induction Melter (CIM5) to evaluate the system's ability to process potential product loading extremes that may be encountered during $\mathrm{Am} / \mathrm{Cm}$ vitrification in the F-Canyon MPPF. These demonstrations of the CIM5 vitrification system employed the Automated Power Control feature to dry, calcine, vitrify and homogenize the glass product, per the request of the Design Authority as Task 3.06 of Technical Task Request 99-MNSS/SE-006. The target glass loading for the $\mathrm{Am} / \mathrm{Cm}$ immobilization has been previously defined at $49 \mathrm{wt} \%$ lanthanides $(\mathrm{Ln})^{1}$, however variations in the $\mathrm{Am} / \mathrm{Cm}$ processing in F-Canyon may result in product loading ranging from 45 to $53 \mathrm{wt} \% \mathrm{Ln}$. This evaluation demonstrates the CIM5 system's ability to vitrify feed streams of the specified extremes.

\section{SUMMARY}

The batch bed volume expansion typically observed when processing the standard 49 wt\% Ln loaded 25SrABS glass was evident to varying degrees when processing batches loaded from 45 to $53 \mathrm{wt} \% \mathrm{Ln}$ in the CIM $5^{2}$. At $45 \mathrm{wt} \% \mathrm{Ln}$ a bed volume expansion that contacted the insulating cover was experienced.

The quantity of cullet used in the 45 and $47 \mathrm{wt} \%$ Ln runs was increased relative to the 49 wt\% Ln target to reduce the Ln loadings. This method for evaluating lower Ln loadings could result from over batching the amount of cullet added to the melter. Another route to the lower Ln loading is from a reduced quantity of oxalate precipitate caused by a dilute feed to the precipitator (e.g. lower solids loading $-77 \mathrm{~g} / 1$ versus $100 \mathrm{~g} / \mathrm{l}$ ). A run to evaluate the lower solids loading did not result in an appreciable volume expansion. This information definitely links the propensity for a volume expansion to the quantity of cullet added to the melter and points out the need to avoid the possibility of over batching cullet to the melter in MPPF.

There were no indications of devitrification in the product glass or the residual glass remaining within the drain tube at the conclusion of the runs. Confirmation of the lanthanide loading was determined by analysis of final glass product samples from each run by the SRTC Mobile Laboratory. Based on the results of these six runs, it may be concluded that the magnitude of the batch volume expansion is directly related to the quantity of cullet in the initial batch. An overcharge greater than $13 \%$ above the baseline amount during cullet addition could result in a severe bed expansion. Calculations show that process variations in MPPF must be very large to change the lanthanide content of the glass beyond the region tested. Variations of this type should not occur during normal processing, and would be considered significant process upsets if they did. 
WSRC-TR-99-00475

ITS-99-0100

Page 2 of 11

\section{EVALUATION RUN DETAILS}

For each of the six Ln loading evaluation runs, a precise quantity of $25 \mathrm{SrABS}$ cullet was added to the CIM5 vessel, followed by $619 \mathrm{~g}$ surrogate oxide in the wet oxalate precipitate produced from a 6.9 liter batch in the coupled precipitator, to yield the final glass product ${ }^{3}$. Details of the runs are listed in Table 1 below.

Table 1.

25SrABS Cullet Additions

\begin{tabular}{|c|c|c|c|c|c|c|}
\hline $\begin{array}{c}\text { Run } \\
\#\end{array}$ & $\begin{array}{c}\text { Targeted Lanthanide } \\
\text { Content of Glass } \\
\text { Product } \\
\text { wt\% Ln } \\
\text { (Oxide Basis) }\end{array}$ & $\begin{array}{c}\text { Actual Lanthanide } \\
\text { Content of Final } \\
\text { Glass * } \\
\text { wt\% Ln } \\
\text { (Oxide Basis) }\end{array}$ & $\begin{array}{c}\text { 25SrABS } \\
\text { Cullet Addition } \\
\text { Amount }\end{array}$ & $\begin{array}{c}\text { Product Glass } \\
\text { Amount }\end{array}$ & $\begin{array}{c}\text { Surrogate } \\
\text { Loading }\end{array}$ & $\begin{array}{c}\text { Surrogate Oxides } \\
\text { from Oxalate } \\
\text { Precipitation }\end{array}$ \\
\hline & & & & Grams & $\%$ & Grams \\
\hline 20 & 53 & 52.69 & 1039.0 & 1658.0 & 37.3 & 619 \\
\hline 21 & 51 & 49.74 & 1166.6 & 1785.6 & 34.7 & 619 \\
\hline 24 & 49 & 46.29 & 1315.4 & 1934.4 & 32.0 & 619 \\
\hline 22 & 47 & 45.79 & 1491.2 & 2110.2 & 29.3 & 619 \\
\hline 23 & 45 & 42.65 & 1702.3 & 2321.3 & 26.7 & 619 \\
\hline 27 & 45 & 43.99 & 1315.4 & 1792.4 & 26.7 & 477 \\
\hline
\end{tabular}

* Sample results are within the margin of analytical error

Two CIM5 runs (runs \#20 and \#21) were made to process batches to yield higher than the established standard $49 \mathrm{wt} \% \mathrm{Ln}$ loaded $25 \mathrm{SrABS}$ glass. The initial quantity of cullet was decreased below the standard, while the quantity of surrogate oxides from the coupled precipitator run was maintained at the standard 619 grams. Likewise, two CIM5 runs (runs \#22 and \#23) were made to process batches to yield lower than the established standard $49 \mathrm{wt} \% \mathrm{Ln}$ loaded $25 \mathrm{SrABS}$ glass by increasing the initial quantity of cullet while the quantity of surrogate oxides was maintained at the standard 619 grams. The goal of run \#24 was to provide baseline data by producing a standard $49 \mathrm{wt} \% \mathrm{Ln}$ loaded 25SrABS glass. CIM5 run \#27 was conducted to process a batch to yield lower than the standard $49 \mathrm{wt} \% \mathrm{Ln}$ loaded $25 \mathrm{SrABS}$ glass by decreasing the quantity of oxides in the precipitate feed to $77 \mathrm{~g} / \mathrm{L}$, while maintaining the quantity of cullet at the standard $49 \mathrm{wt} \%$ Ln glass level.

\section{3 wt\% Ln Loaded 25SrABS Glass Run}

Run \#20 was the first run to evaluate the process effects of decreasing the quantity of 25SrABS cullet batched to the melter to result in a higher final glass loading of $53 \mathrm{wt} \%{ }^{4}$. The drying and calcination processes proceeded as expected. The small volume expansion typically observed during the vitrification phase of a standard $49 \mathrm{wt} \% \mathrm{Ln}$ loaded batch run was substantially decreased in magnitude. The vessel was drained in 2 minutes 30 seconds after initiating pouring, yielding a homogeneous glass product. Based on the results of this run, no adverse conditions are anticipated in the MPPF operations should the product loading vary as high as $53 \mathrm{wt} \% \mathrm{Ln}$. Temperature data for the $53 \mathrm{wt} \%$ Ln Loaded 25SrABS Glass Run are shown in Figure 1. The magnitude of a 
WSRC-TR-99-00475

ITS-99-0100

Page 3 of 11

batch bed volume expansion is typically indicated by an accelerated rise in temperature indicated by the vessel T1B thermocouple, located 4-1/2" below the top of the vessel.

Figure 1. CIM5 TTR Run \#20 - 53 wt\% Ln Loaded 25SrABS Glass Run

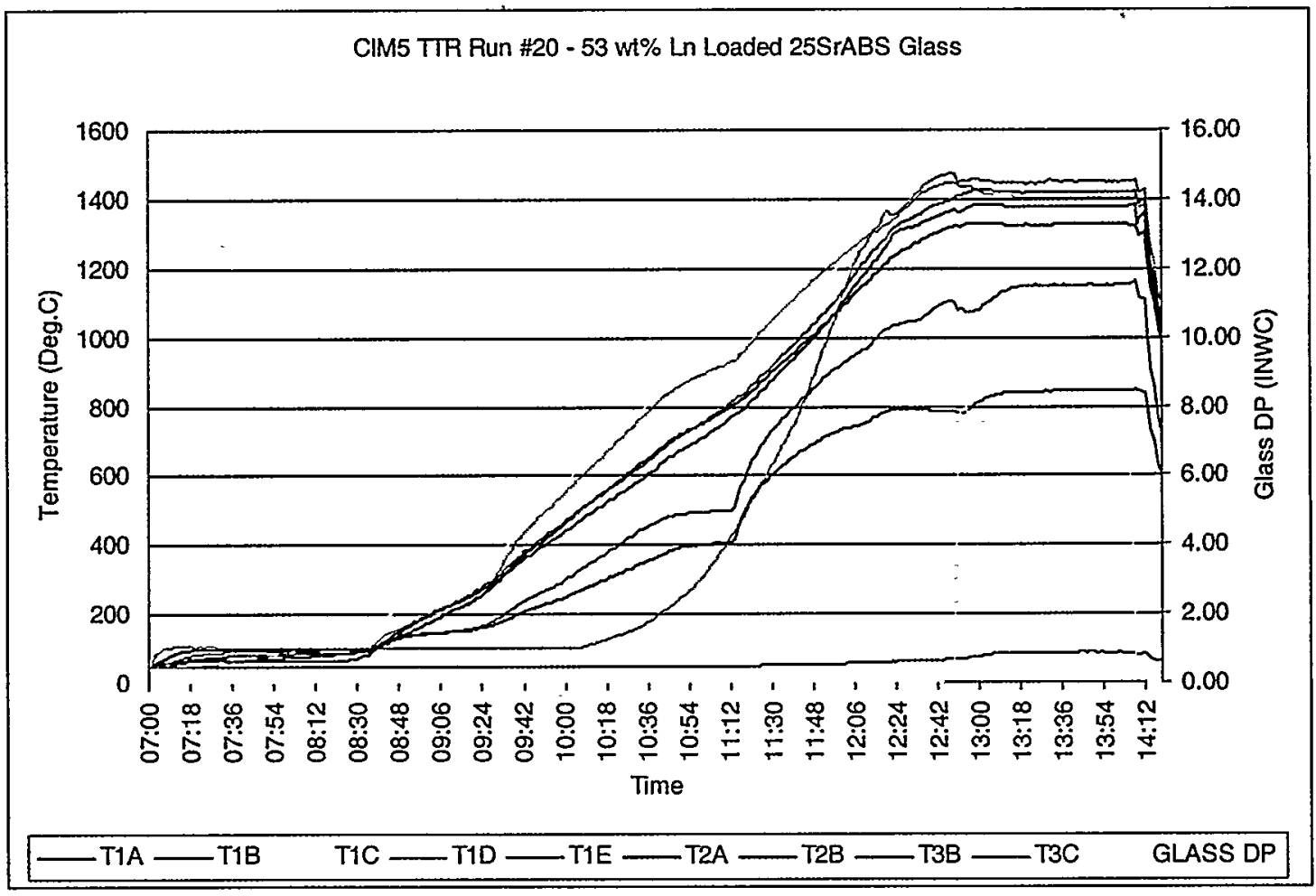

\section{1 wt\% Ln Loaded 25SrABS Glass Run}

Run \#21 was conducted to evaluate the process effects producing a final glass loading of $51 \mathrm{wt} \% \mathrm{Ln}^{5}$. The drying and calcination processes proceeded as expected. The small volume expansion typically observed during the vitrification phase of a standard $49 \mathrm{wt} \%$ Ln loaded batch run was again decreased in magnitude. The vessel was drained in 3 minutes 10 seconds after initiating pouring, resulting in a homogeneous glass product. This run showed no adverse conditions are anticipated in the MPPF operations should the product loading vary as high as $51 \mathrm{wt} \%$ loading. Temperature data for the $51 \mathrm{wt} \% \mathrm{Ln}$ Loaded 25SrABS Glass Run are shown in Figure 2.

\section{7 wt\% Ln Loaded 25SrABS Glass Run}

Run \#22 was conducted to evaluate the process effects of increasing the quantity of $25 \mathrm{SrABS}$ cullet batched to the melter to result in a lower final glass loading of $47 \mathrm{wt} \%$ Ln ${ }^{6}$. The drying and calcination processes proceeded as expected. The volume 
WSRC-TR-99-00475

ITS-99-0100

Page 4 of 11

expansion, typically observed during the vitrification phase of a standard $49 \mathrm{wt} \% \mathrm{Ln}$ loaded batch run, was slightly increased in magnitude. The vessel was drained in 5 minutes 30 seconds after initiating pouring, again producing a homogeneous glass product. This run showed no adverse conditions are anticipated in the MPPF operations should the product loading vary as low as $47 \mathrm{wt} \%$ loading. Temperature data for the 47 wt\% Ln Loaded 25SrABS Glass Run are shown in Figure 3.

\section{5 wt\% Ln Loaded 25SrABS Glass Run}

Run \#23 was conducted to evaluate the process effects of increasing the quantity of $25 \mathrm{SrABS}$ cullet batched to the melter to result in a final glass loading of $45 \mathrm{wt} \% \mathrm{Ln}$. The drying and calcination processes proceeded as expected. The volume expansion, typically observed during the vitrification phase of a standard $49 \mathrm{wt} \% \mathrm{Ln}$ loaded batch run, was significantly increased in magnitude. Within minutes of entering the peak power soak/sparging phase of the run, the bed expansion increased to the point of lifting the insulating cover board over the vessel. The expansion appeared to pulse as gasses continued to evolve from within the batch bed, rising upward before sinking back into the melter vessel as the trapped gas was vented. The vessel was drained in 7 minutes 9 seconds after initiating pouring, yielding a homogeneous glass product. Temperature data for the $45 \mathrm{wt} \% \mathrm{Ln}$ Loaded 25SrABS Glass Run are shown in Figure 4.

It appears that as the quantity of cullet in the batch is increased, (which is done to reduce the final lanthanide loading of the glass product) the propensity for a volume expansion increases. This is consistent with previous observations. This method for evaluating lower lanthanide loadings is considered conservative. In MPPF lower lanthanide loading would most likely result from a reduced quantity of oxalate precipitate (e.g. lower dissolved solids loading) coupled with the same amount of cullet.

\section{9 wt\% Ln Loaded 25SrABS Glass Run}

Run \#24 was conducted as a control case for comparison to the other runs to evaluate the process effects of deviating from the standard final glass loading of $49 \mathrm{wt} \% \mathrm{Ln}^{8}$. The drying and calcination processes proceeded as expected. The volume expansion was identical to that typically observed during the vitrification phase of the standard 49-wt\% Ln loaded runs. The vessel was drained in 4 minutes 15 seconds after pouring was initiated, resulting in a homogeneous glass product. Temperature data for the standard 49 wt\% Ln Loaded 25SrABS Glass Run are shown in Figure 5.

\section{5 wt\% Ln Loaded 25SrABS Glass Run (77g/L oxides)}

Run \#27 was conducted to evaluate the process effects of decreasing the quantity of oxides in the surrogate feed to result in a lower final glass loading of $45 \mathrm{wt} \% \mathrm{Ln}{ }^{9}$. The standard quantity of $25 \mathrm{SrABS}$ cullet for yielding a $49 \mathrm{wt} \% \mathrm{Ln}$ loaded glass was used. A slightly greater quantity of free liquid was present above the batch solids bed prior to 
WSRC-TR-99-00475

ITS-99-0100

Page 5 of 11

initiation of heating (2-5/8" vs standard 2-1/4") but this did not appreciably affect the drying process. The volume expansion was reduced in magnitude as compared to that typically observed during the vitrification phase of a standard $49 \mathrm{wt} \% \mathrm{Ln}$ loaded batch run and significantly reduced as compared to that observed during the $45 \mathrm{wt} \% \mathrm{Ln}$ loaded batch with increased cullet. After 75 minutes of sparging the glass with argon at $1.5 \mathrm{scfh}$, the vessel was drained in 5 minutes 36 seconds after initiating pouring, producing a homogeneous glass product. Temperature data for the $45 \mathrm{wt} \%$ Ln Loaded 25SrABS Glass Run are shown in Figure 6.

This run demonstrated the importance in controlling the quantity of cullet charged to the melter vessel for each run. A direct correlation exists between the quantity of cullet in the batch and the magnitude of the bed expansion exhibited. A marked improvement was demonstrated by this run, showing the importance in assuring the correct quantity of cullet (1315.4 grams) is used for processing.

Figure 2. CIM5 TTR Run \#21 - 51 wt\% Ln Loaded 25SrABS Glass Run

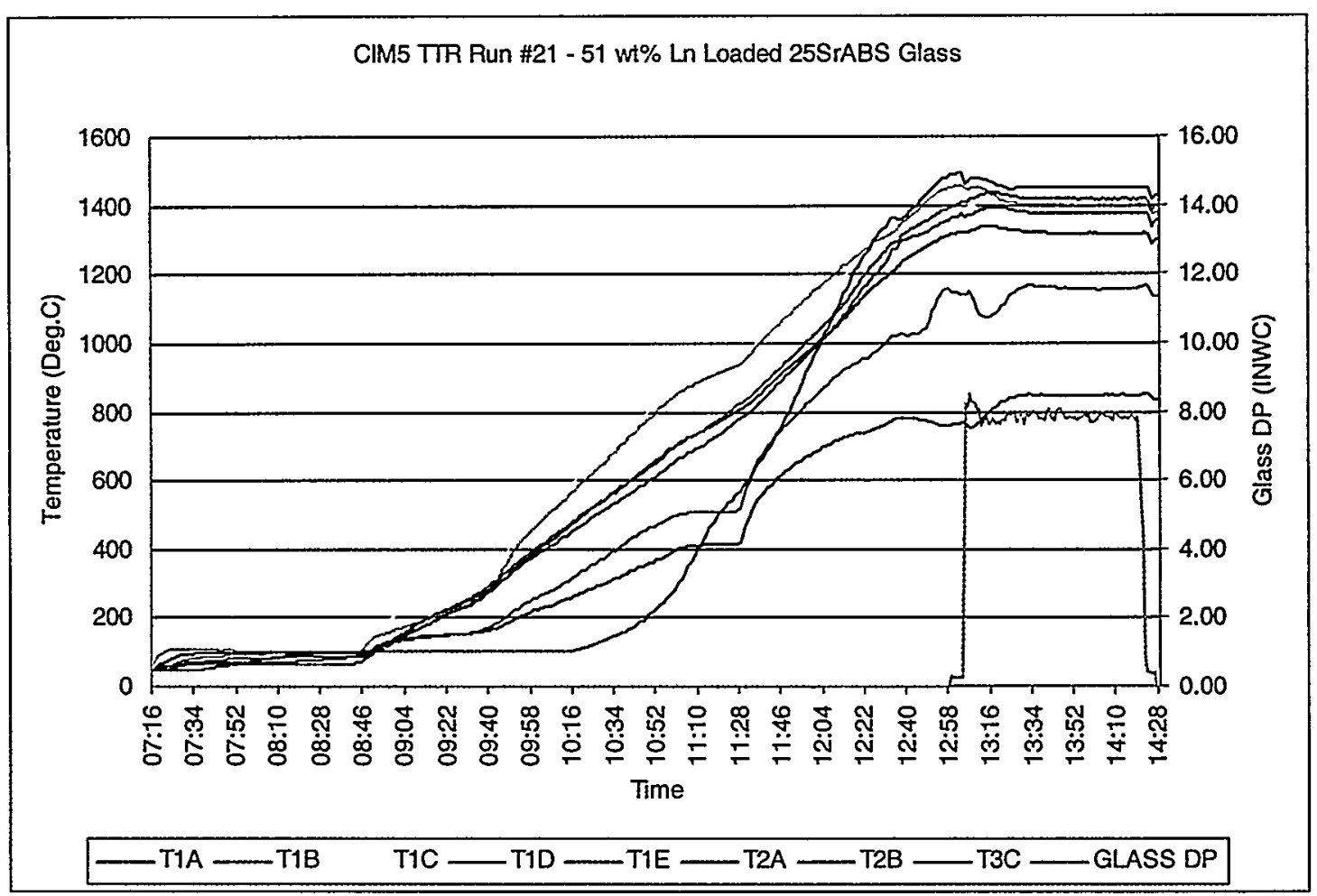


- WSRC-TR-99-00475

ITS-99-0100

Page 6 of 11

Figure 3. CIM5 TTR Run \#22-47 wt\% Ln Loaded 25SrABS Glass Run

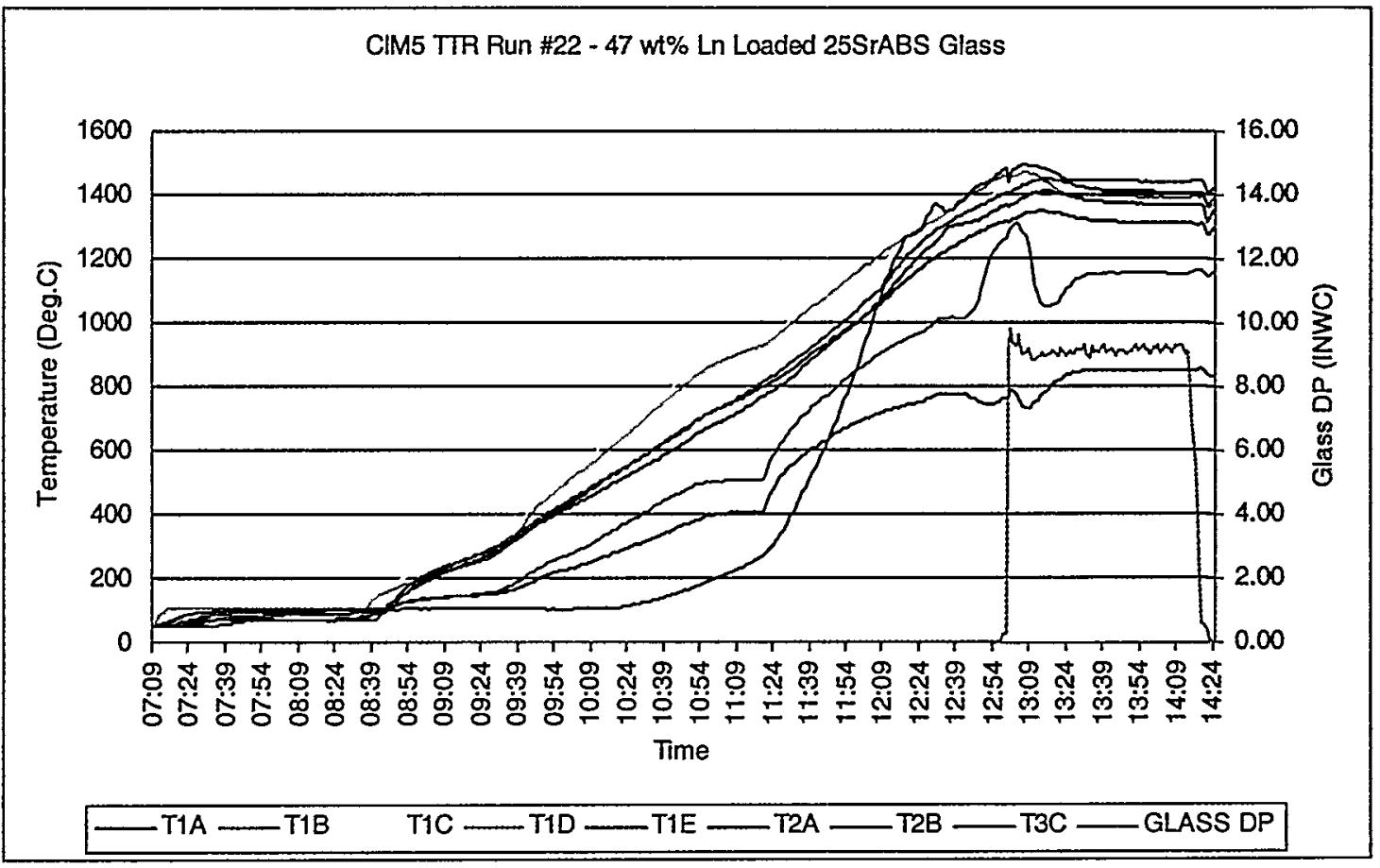

Figure 4. CIM5 TTR Run \#23 - 45 wt\% Ln Loaded 25SrABS Glass Run

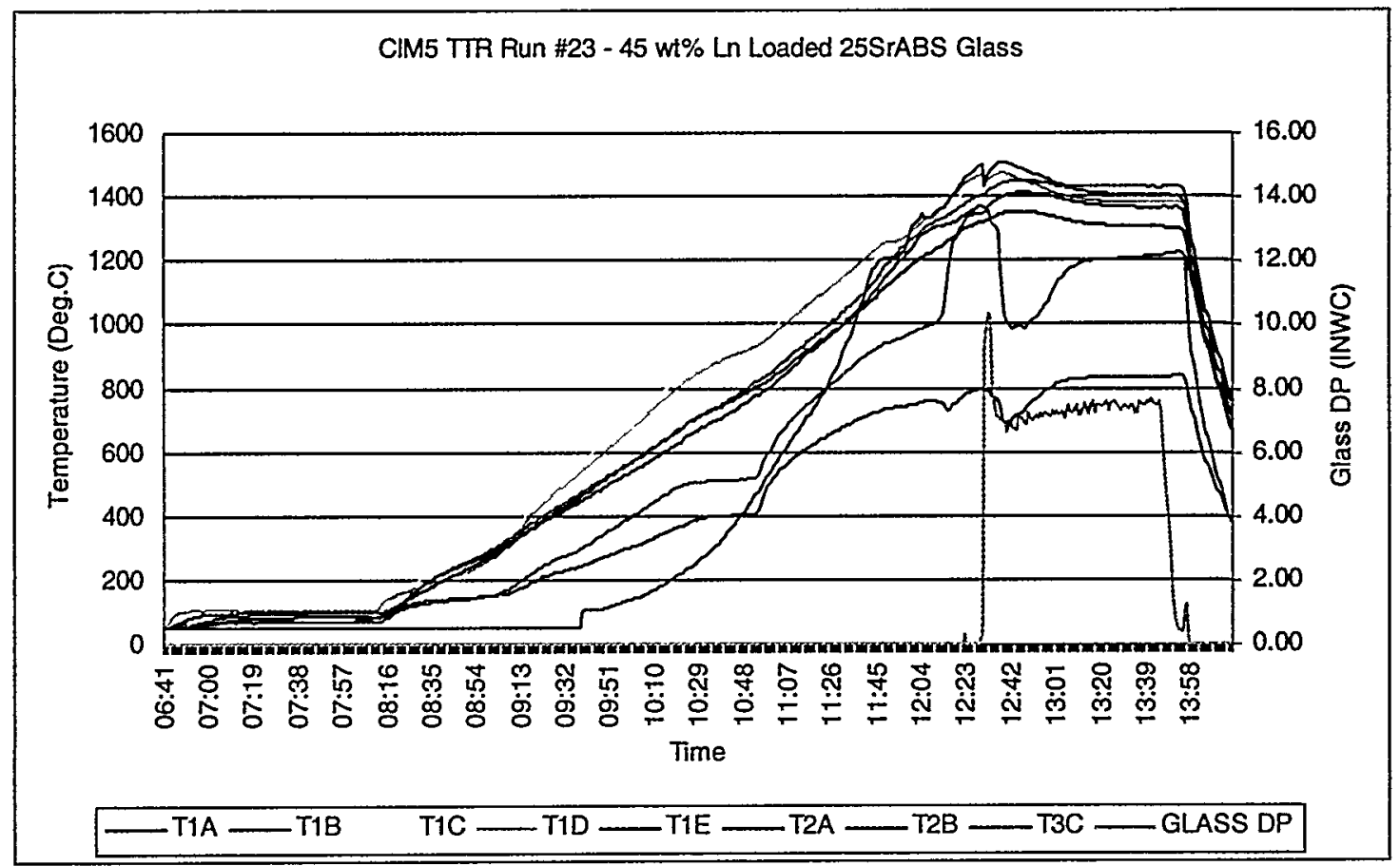


WSRC-TR-99-00475

ITS-99-0100

Page 7 of 11

Figure 5. CIM5 TTR Run \#24 - Standard 49 wt\% Ln Loaded 25SrABS Glass Run

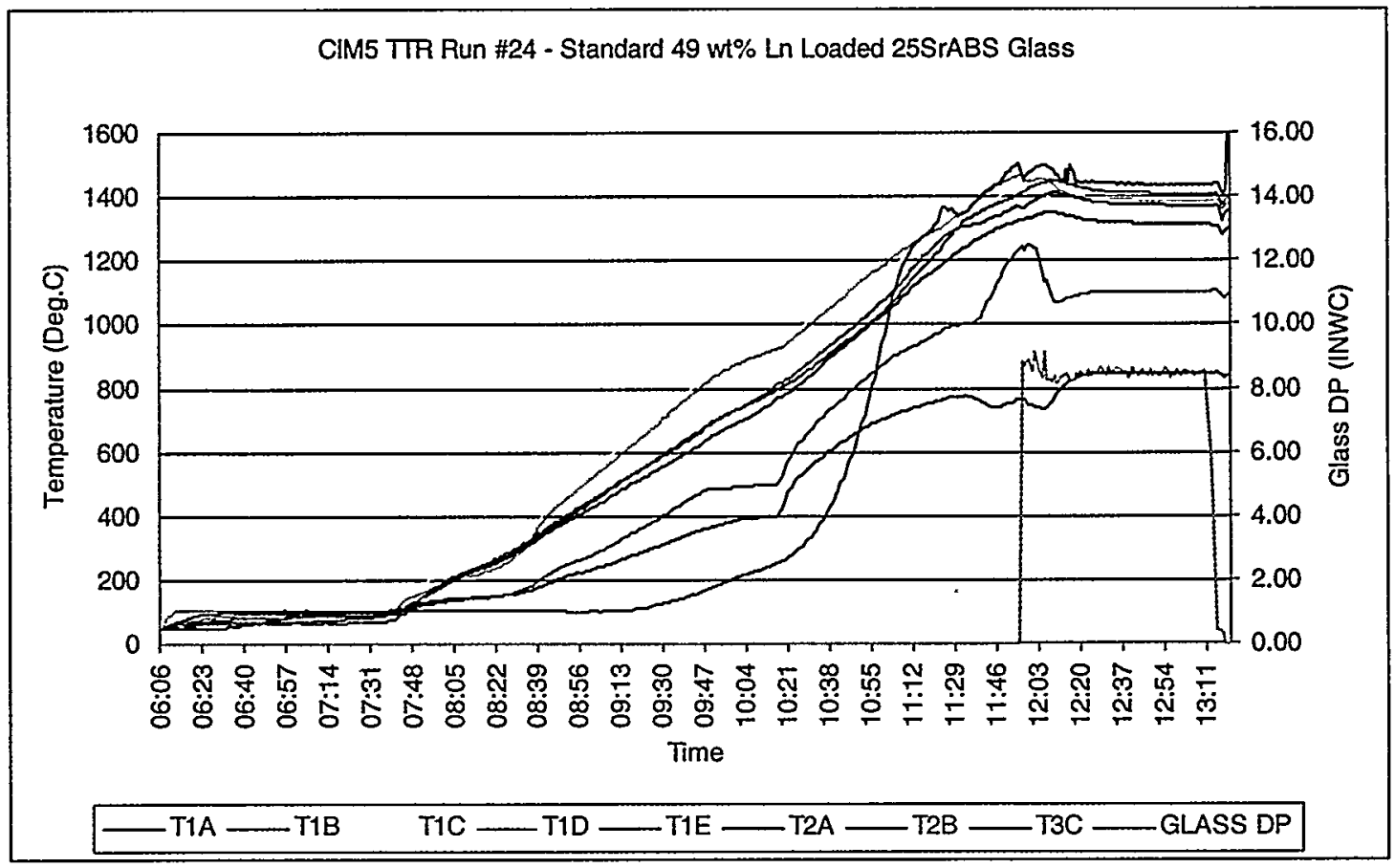

Figure 6. CIM5 TTR Run \#27 - 45 wt\% Ln Loaded 25SrABS Glass Run (77 g/L oxides)

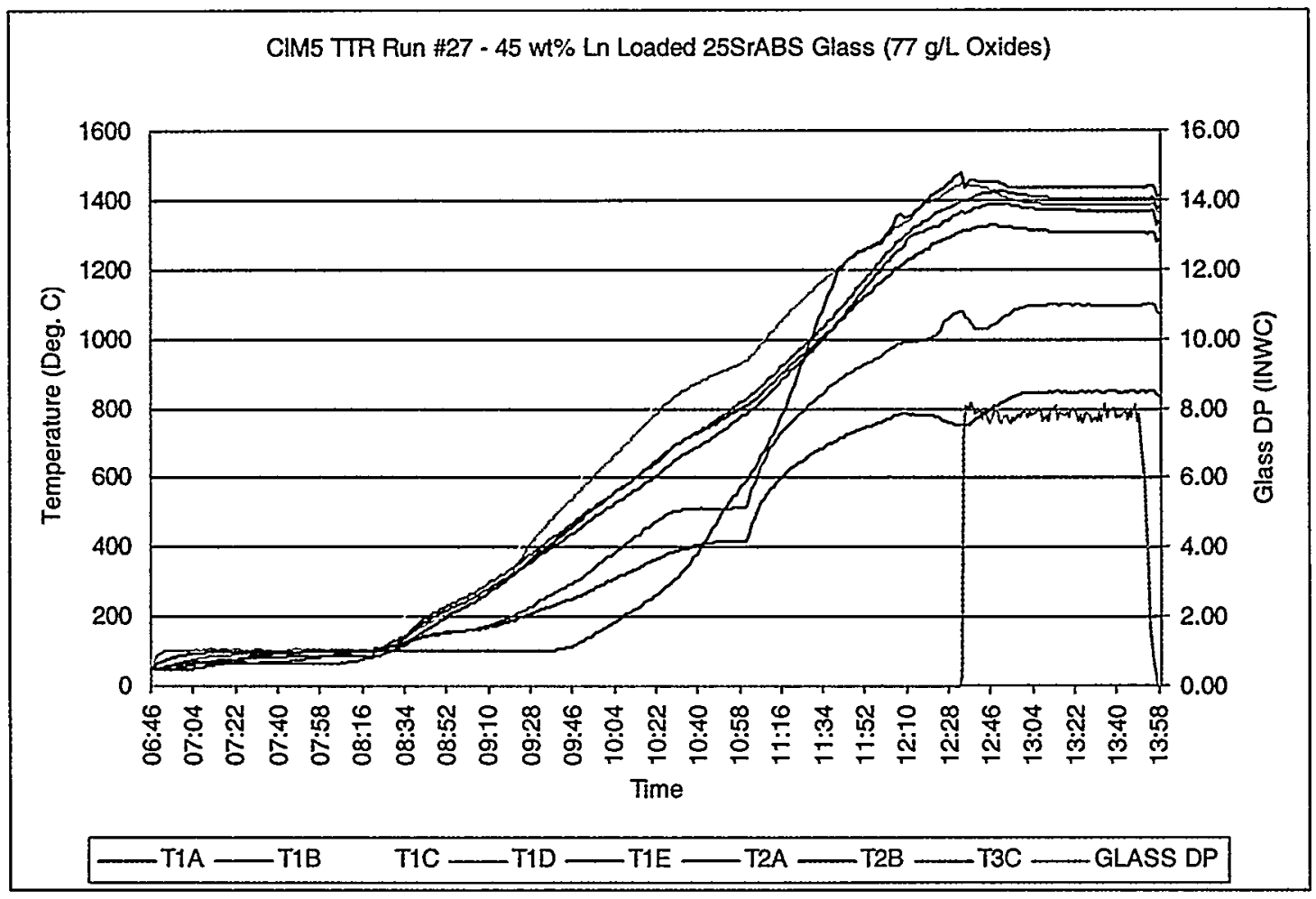




\section{EFFECT OF VARIATION IN PROCESS ON LANTHANIDE CONTENT OF GLASS}

The lanthanide content of the glass product is determined by four process variables: the amount of $25 \mathrm{SrABS}$ cullet added to melter, the precipitation batch volume, the solids concentration of the feed solution, and the precipitation yield. The effect of changes in these variables on the lanthanide content was calculated and charted to determine if the range of lanthanide loading evaluated (45\% to 53\%) during the testing was sufficient to account for expected deviations in the parameters. The calculations assumed normal process parameters based on the $\mathrm{Am} / \mathrm{Cm}$ material balance: precipitation batch volume was 6.91 liters, the feed concentration was 100 grams/liter on an oxide basis, the precipitation yield was $95.5 \%$, and the cullet addition was 1254 grams.

\section{Effect of Changes in 25SrABS Cullet Addition}

Figure 7 shows the lanthanide content of the glass plotted versus amount of cullet added. As shown by the chart, an error of 300 grams in the baseline cullet addition would be required to change the lanthanide content of the glass beyond the region tested. When the cullet addition was increased to yield a $45 \mathrm{wt} \% \mathrm{Ln}$ loaded glass, a severe bed expansion was observed; therefore errors in cullet addition that would cause the wt $\%$ Ln loading to decrease below $47 \%$ must be avoided. A cullet over-batch greater than 176 grams (13\%) must be avoided.

Figure 7. Lanthanide Content of Glass versus 25SrABS Cullet Addition Amount

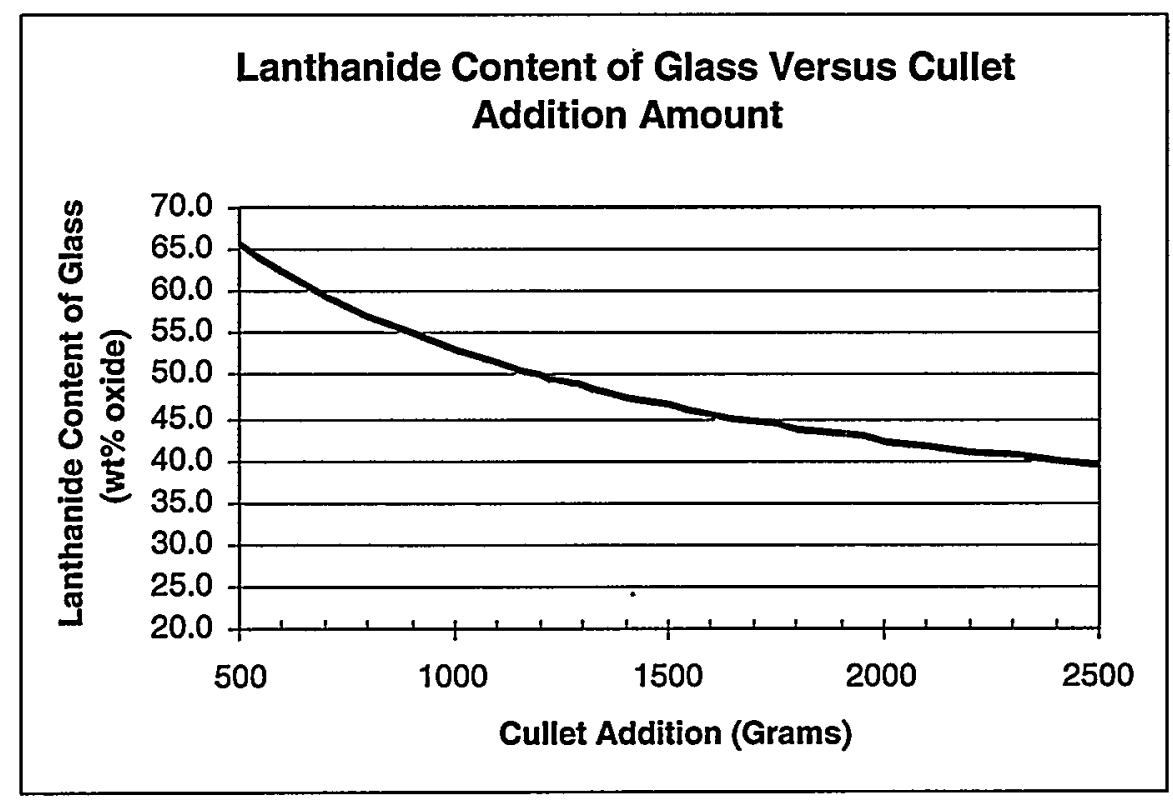


WSRC-TR-99-00475

ITS-99-0100

Page 9 of 11

\section{Effect of Changes in Precipitation Batch Volume}

Figure 8 shows the lanthanide content of the glass plotted versus precipitation batch volume. As shown by the chart, an error of 1.5 liters would be required to change the lanthanide content of the glass beyond the region tested.

Figure 8. Lanthanide Content of Glass versus Precipitation Batch Volume

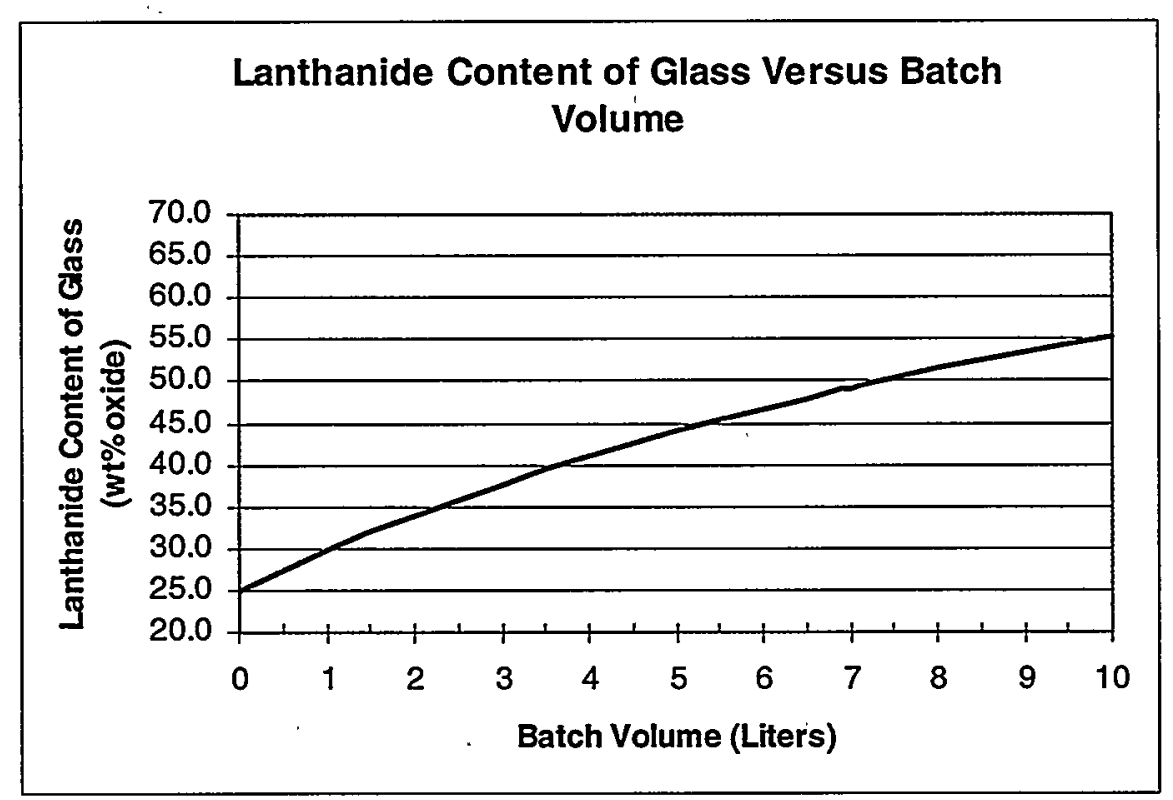

\section{Effect of Changes in Precipitation Yield}

Figure 9 shows the lanthanide content of the glass plotted versus yield. As shown by the chart, precipitation yields below $75 \%$ would be required to change the lanthanide content of the glass beyond the region tested.

Figure 9. Lanthanide Content of Glass versus Precipitation Yield

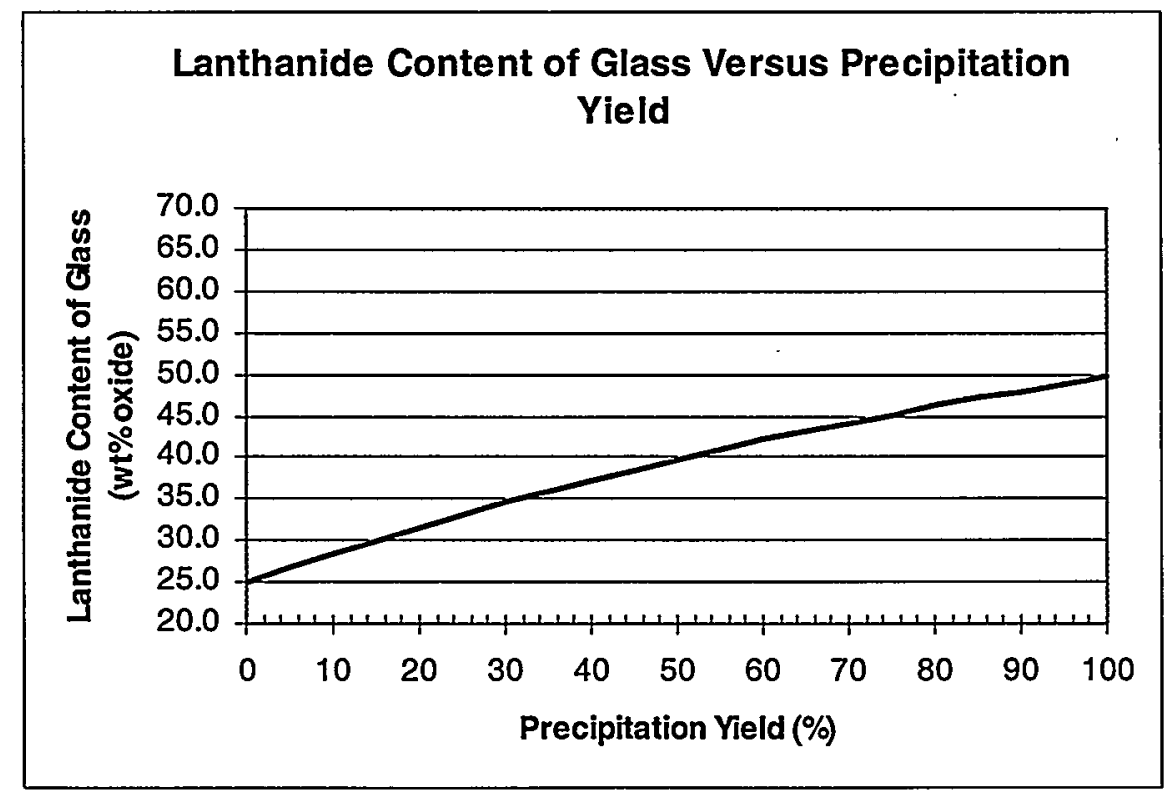


WSRC-TR-99-00475

ITS-99-0100

Page 10 of 11

\section{Effect of Changes in Feed Solution Concentration}

Figure 10 shows the lanthanide content of the glass plotted versus feed solution concentration. As shown by the chart, an error of 20 grams per liter would be required to change the lanthanide content of the glass beyond the region tested.

Figure 10. Lanthanide Content of Glass versus Feed Solution Concentration

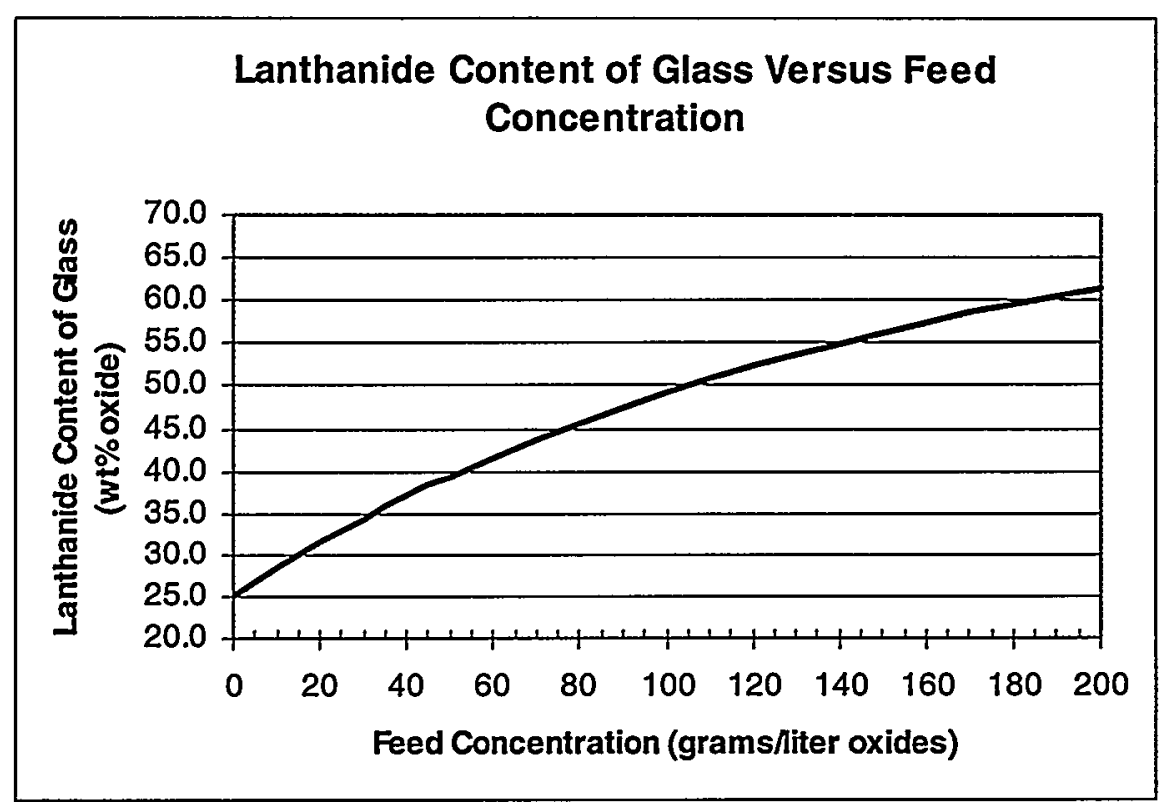

The calculations show that process variations in MPPF must be very large to change the lanthanide content of the glass beyond the region tested. Variations of this type would not be expected to occur during normal processing and would be considered significant process upsets.

\section{REFERENCES}

1. T. M. Jones and D.C. Witt, CIM5 Phase III Base Process Development Results (U), SRT-TR-99-00434, November 24, 1999.

2. WSRC-NB-99-00173, CIM5 Laboratory Notebook

3. M. E. Stone, Am/Cm Pilot Facility Revised Cullet Addition Calculations (U), SRT-AMC-99-0204, September 29, 1999.

4. T. M. Jones and D. C. Witt, CIM5 TTR Run \#20 - Task 3.06 - Off-normal Ln Loading (53 wt\%) (U), SRT-AMC-99-0219, November 29, 1999.

5. T. M. Jones and D. C: Witt, CIM5 TTR Run \#21 - Task 3.06 - Off-normal Ln Loading (51 wt\%) (U), SRT-AMC-99-0220, November 30, 1999. 
WSRC-TR-99-00475

ITS-99-0100

Page 11 of 11

6. T. M. Jones and D. C. Witt, CIM5 TTR Run \#22 - Task 3.06 - Off-normal Ln Loading (47 wt\%) (U), SRT-AMC-99-0221, December 1, 1999.

7. T. M. Jones and D. C. Witt, CIM5 TTR Run \#23 - Task 3.06 - Off-normal Ln Loading (45 wt\%) (U), SRT-AMC-99-0222, December 2, 1999.

8. T. M. Jones and D. C. Witt, CIM5 TTR Run \#24 - Task 3.06 - Off-normal Ln Loading (Standard 49 wt\%) (U), SRT-AMC-99-0229, December 6, 1999.

9. T. M. Jones and D. C. Witt, CIM5 TTR Run \#27 - Task 3.06 - Off-normal Ln Loading (45 wt\%) From 77g/L Feed (U), SRT-AMC-99-0233, December 10, 1999.

10. F. G. Smith, Am/Cm Vitrification Process: Vitrification Material Balance Calculations (U), SRT-AMC-99-0210, January 10, 2000. 


\section{DISTRIBUTION:}

L. M. Papouchado, 773-A

E. W. Holtzscheiter, 773-A

L. F. Landon, 704-1T

M. A. Baich, 704-1T

D. C. Witt, 704-1T

T. M. Jones, 704-1T

D. H. Miller, 704-1T

M. E. Stone, 704-1T

T. K. Snyder, 704-T

D. K. Peeler, 773-43A

C. B. Miller, 773-A

Am/Cm File, 704-1T

STI, 703-43A (4) 